\title{
Institutions and Scientific Progress
}

\author{
C. Mantzavinos
}

Forthcoming in: Philosophy of the Social Sciences, 2021 


\begin{abstract}
Scientific progress has many facets and can be conceptualized in different ways, for example in terms of problem-solving, of truthlikeness or of growth of knowledge. The main claim of the paper is that the most important prerequisite of scientific progress is the institutionalization of competition and criticism. An institutional framework appropriately channeling competition and criticism is the crucial factor determining the direction and rate of scientific progress, independently on how one might wish to conceptualize scientific progress itself. The main intention is to narrow the divide between traditional philosophy of science and the sociological, economic and political outlook at science that emphasizes the private interests motivating scientists and the subsequent contingent nature of the enterprise. The aim is to show that although science is a social enterprise taking place in historical time and thus is of a contingent nature, it can and in fact does lead to genuine scientific progress - contrary to the claims of certain sociologists of science and other relativists who standardly stress its social nature, but deny its progressive character. I will first deal with the factual issue by way of introducing the main concepts and mechanisms of modern institutional theory and by applying them to the analysis of the cultural phenomenon that we call modern science. I will then turn to the normative issue: what is the appropriate content of the institutional framework, for scientific progress to emerge and be sustained at which level should it be set and by whom? Addressing this problematic is equivalent to conducting a constitutional debate leading to a Constitution of Science.
\end{abstract}

Keywords: institutions; new institutionalism; criticism; self-organization; scientific progress; Popper 


\section{Introduction}

The performance of science in relation to other forms of knowledge is preeminent. This is due to the fact that progress in knowledge has turned out to be possible in the course of history. Modern science is a constituent part of culture which also includes other systems like art, religion and law. It is embedded, as are all such systems, in a social context without which it could not exist. Its characteristic form depends on a distinct institutional arrangement which channels its operation and allows its steering in a specific way (Jarvie, 2001).

Scientific progress has many facets and can be conceptualized in different ways, for example in terms of problem-solving, of truthlikeness or of growth of knowledge. My main claim is that the most important prerequisite of scientific progress is the institutionalization of competition and criticism. An institutional framework appropriately channeling competition and criticism is the crucial factor determining the direction and rate of scientific progress, independently on how one might wish to conceptualize scientific progress itself. My main intention is to narrow the divide between traditional philosophy of science that elaborates on the standards defining science as a truth-seeking enterprise and the sociological, economic and political outlook at science that emphasizes the private interests motivating scientists and the subsequent contingent nature of the enterprise. My aim is to show that although science is a social enterprise taking place in historical time and thus is of a contingent nature, it can and in fact does lead to genuine scientific progress - contrary to the claims of certain sociologists of science and other relativists who standardly stress its social nature, but deny its progressive character, following the lead of Bloor (1976/1991), Latour and Woolgar (1979/1986) or Rorty (1979).

The key is to focus on the complex institutional matrix that defines the way that scientists interact in their daily activities and which crucially shapes their outcomes. The factual issue concerns the question of how science actually works as a social process within an institutional framework which is itself evolving. The normative issue concerns the 
question of what kind of institutional provisions would be required, if the competitive efforts of the participants are to enable scientific progress. I will first deal with the factual issue by way of introducing the main concepts and mechanisms of modern institutional theory and by applying them to the analysis of the cultural phenomenon that we call modern science. I will then turn to the normative issue: what is the appropriate content of the institutional framework, for scientific progress to emerge and be sustained at which level should it be set and by whom? Addressing this problematic is equivalent to conducting a constitutional debate leading to a Constitution of Science.

\section{Institutions: Emergence and Evolution}

"Institutions keep society from falling apart, provided that there is something that keeps institutions from falling apart" (Elster, 1989, 147). This phrase by Jon Elster nicely summarizes the relevance of institutions for society ${ }^{1}$.

Institutions are normative social rules, that is the rules of the game in a society, enforced either through the coercive power of the state or other enforcement agencies that shape human interaction (Mantzavinos, 2001). They constitute normative patterns of behavior that provide solutions to problems of coordination and cooperation in society in virtue of offering a quasi-permanent platform of conflict resolution. Institutions as the rules of the

\footnotetext{
${ }^{1}$ In the last decades we have been witnessing the development of a research program, New Institutionalism, which has provided a series of mechanisms for the explanation of the ways that institutions shape human interaction in society, markets and politics. New Institutional Economics, for example, has become widely accepted, mainly as it has been shaped by the works of Ronal Coase (1937, 1960), Douglass C. North $(1981,1990,1994,2005,2009)$ and Oliver Williamson $(1985,1996)$ who all won the Nobel memorial prize in Economic Sciences. In Sociology and Political Science, New Institutionalism has been shaped by the work of a series of authors in three different versions (Hall and Taylor 1998), that is, historical institutionalism (Hall 1986, Thelen 2004, Mahoney and Thelen 2015, Pierson, 2004), rational choice institutionalism (Riker, 1980, Shepsle, 1986, 1989, 2006, Levi 1988, Knight 1992, Tsebelis, 2002, 2017) and sociological institutionalism (DiMaggio and Powell, 1991, Nee and Brinton 1998, Meyer, 2010) culminating with the Nobel memorial prize in Economic Sciences awarded to the political scientist Elinor Ostrom for her interdisciplinary work on institutional analysis $(1990,2005)$. On the ongoing discussion on New Institutionalism in Anthropology see Ensminger (1992, 2014) and in Classics see Ober (2015) and Bresson (2016).
} 
socioeconomic game define what kind of strategies and which action parameters can be employed by agents in their activities.

Institutions must be distinguished from organizations (North, 1990). Institutions are the rules of the game; organizations are corporate actors, that is, groups of individuals bound by some rules designed to achieve a common objective (Coleman, 1990). They can be research organizations such as universities, political organizations such as political parties or economic organizations such as corporations. Organizations and individuals are the players in the game. When individuals and organizations interact, they are attending the general normative rules which we called institutions, i.e. the rules of the game, which constrain their behavior.

After defining institutions and providing the distinction between institutions and organizations, we can ask the most fundamental question of the theory of institutions: Why do institutions exist? One has used different approaches to answer this question, but it is the individualistic approach that I will follow here, according to which there are two broad classes of causes that can explain the existence of institutions. The first class includes the causes that have to do with the motivational structure of homo sapiens and the second with the cognitive one. If one starts with the common hypothesis about motivation, that is that individuals strive to better their condition by the means available to them, formalized in the idea of increasing her own utility, then an interindividual conflict is bound to arise. The patterns of such conflicts are distinct and observable from an observer's point of view and are systematized and formalized by contemporary game theory (e.g. Dixit et al. 2015, Guala 2016), such as the well-known prisoner's dilemma, the coordination game, the game of trust and many more. Such settings are "social" not in the sense that the agents are consciously aware of them, but in the sense that they are identifiable by the social scientist. The most fundamental raison $\mathrm{d}^{\prime}$ être of institutions is, thus, that they provide workable solutions to social problems, most of which of a conflictual character. Institutions help partially overcome the Hobbesian problem: the life of man in a society without institutions would be, in the words of Hobbes (1651/1991, 89), "solitary, poore, nasty, brutish and short". 
But why do people adopt institutions, that is, social normative rules, rather than deciding each time anew on how to solve a social conflict? Since every problem situation has unique characteristics, why not solve social problems ad hoc? The second class of causes for the existence of institutions provides an answer to this question. These causes have to do with the cognitive structure of humans. Humans avail only of limited cognitive capacities which are mobilized only when they are confronted with "new problems" in their environment; they follow routines when they classify the problem situations as familiar ones (Mantzavinos, 2001; Mantzavinos, North, Shariq, 2004). This distinction is rooted in the limited computational capacity of human beings (Simon, 1983, Gigerenzer, 2008; 2019). In a genuinely uncertain environment, that is an environment characteristic of a non-ergodic world (North, 2005, ch. 1) the mind must be freed up from unnecessary operations, so that the problems in such an environment can be tackled at all and dealt with adequately. In other words a huge number of mental processes becomes automatized and is not taking place in the light of consciousness and this is the basic cause of showing a routinized behavior. As Bargh and Chartrand point out in a classic article (1999, p. 469): "But what we find most intriguing, in considering how mental processes recede from consciousness over time with repeated use, is that the process of automation itself is automatic. The necessary and sufficient ingredients of automation are frequency and consistency of use of the same set of component mental processes under the same circumstances - regardless of whether the frequency and consistency occur because of a desire to attain a skill, or whether they occur just because we have tended in the past to make the same choices or to do the same thing or to react emotionally or evaluatively in the same way each time. These processes also become automated, but because we did not start out intending to make them that way, we are not aware that they have been and so, when that process operates automatically in that situation, we aren't aware of it". ${ }^{2}$

\footnotetext{
${ }^{2}$ This solid empirical finding, that the limited cognitive faculties of the mind are used thriftily, has been presaged by Whitehead already in 1911 (p. 45f.):

"It is a profoundly erroneous truism, repeated by all copy-books and by eminent people making speeches, that we should cultivate the habit of thinking of what we are doing. The precise opposite is the case. Civilization advances by extending the number of operations which we can perform without thinking about them. Operations of thought are like cavalry charges in a battle - they are strictly limited in number, they require fresh horses, and must only be made at decisive moments".
} 
Our limited cognitive capacity makes our environment appear rather complicated to us and in need of simplification in order to be mastered (Heiner, 1993) - this is what we mean when we say that our environment is complex. This refers to both our natural and our social environment, the latter being the focus here. Rules in general, as Hayek $(1976 / 1982,8)$ put it, "are a device for coping with our constitutional ignorance", they are the "device we have learned to use because our reason is insufficient to master the full detail of complex reality" (Hayek, 1960, 66). Institutions are our devices to deal with recurrent social problems arising in situations where self-interested individuals interact.

A very fruitful and widely used criterion for distinguishing among different types of institutions is the enforcement agency. In other words an institution is not simply a social rule shared by individuals (and organizations), but also the enforcement characteristics of it. One can classify institutions according to this criterion as shown in the following table: 


\begin{tabular}{|c|c|c|}
\hline \multirow{4}{*}{$\begin{array}{c}\text { Informal } \\
\text { Institutions }\end{array}$} & Conventions & Self-policing \\
\cline { 2 - 3 } & Social Norms & $\begin{array}{c}\text { Third Pary: Other } \\
\text { Individuals in the } \\
\text { Group }\end{array}$ \\
\hline Formal & Law & Third Party: State \\
Institutions & & \\
\hline
\end{tabular}

It is impossible to provide a detailed analysis of the emergence and working properties and enforcement of the different types of institutions here. I would only like to highight two general mechanisms of emergence of institutions: they emerge either deliberately or spontaneously, that is, either as a product of collective action or as a product of a spontaneous process of social interaction. The deliberate emergence of institutions has long been the object of inquiry since their explanation is relatively simple - they are explained exclusively by intentional action aimed at establishing them (Knight, 1992). The spontaneous emergence of institutions as originally conceptualized by the Scottish moral philosophers culminating in Adam Ferguson's observation $(1767 / 1966,188)$ that "[n]ations stumble upon establishments which are indeed the result of human action, but not the execution of human design", requires more sophisticated explanatory patterns (e.g. Bicchieri, 2006, 2016). Although the enforcement agency and the specific enforcement mechanism is different for each category of informal institutions, there is a common element to each type of informal institution, i.e. conventions, moral rules and social norms: they all emerge as the unintended outcome of human action. The emergence of informal institutions is, thus, the outcome of a process which is not under the conscious control of any individual mind. Law or the class of the social rules that I have called formal institutions, are on the contrary products of collective decisions. The state as an organization creates law either by providing by means of suitable adaptation existing informal institutions with sanctions or by constructing, by the conscious decision of its organs, altogether novel legal rules. Modern public choice theory provides 
explanations of how collective decisions lead to the emergence of institutions in the social realm (Mueller, 2003). In a nutshell, during the political process individuals and organizations aiming at furthering their interests succeed in a greater or lesser degree while using the power that they have - in influencing the collective decision-making procedures that lead to the creation of legal rules. What is called "political power", however, is a factor that is very difficult to identify. Therefore contemporary positive political theory often uses the proxy of "resources" in order to determine the behavior of the players in the political game. There are usually three kinds of resources that players use in their endeavors, that is, economic, political, and ideological. The extent of the bargaining power of the players is determined by the degree of their availability. Consequently, the resources decisively influence the political process which in the end generates the formal institutions (Moe, 2005).

It is the case, thus, that the mechanisms for the emergence of informal and formal institutions are distinct. The informal institutions emerge endogenously from within society as the unintended results of human action during an invisible-hand process whereas the formal institutions emerge in a way exogenously, in the sense that they are the outcome of the political process driven by the collective decisions of agents availing of resources: political, economic and ideological. There is therefore no necessity that informal and formal institutions complement each other in such a way that a workable social order is produced or that scientific progress takes place.

\section{Science as a Grown Order}

Scientific activity is undertaken by imperfect biological organisms with a limited cognitive capacity in interaction with artefacts in a specific social context. The scientific enterprise is a social process (Hull, 1988), and it consists of the attempt of the participants in this process to provide answers to puzzles and solutions to theoretical problems (Mantzavinos, 2013, 2016). The scientific enterprise is embedded in the institutional framework of the society consisting of informal and formal institutions. 
What we call "science" is not a means toward the accomplishment of anything. It is, instead, the institutional embodiment of the processes of constructing and criticizing solutions to theoretical problems that are entered into by individuals in their several abilities and skills. Individuals are observed to cooperate with one another, to compete with one another, to devise representational vehicles for solving problems, to experiment and criticize one another. The network of relationships that emerges and evolves out of this process is called "science". It is a setting, an arena, in which scientists attempt to accomplish their own purposes, whatever these may be.

The talk of "the aim of science" is not simply a false abstraction; it is a seriously misleading oversimplification. Only an agent can have an aim. This is evident in the case of an individual agent. In the case of a group, one can still plausibly defend the position that it can be viewed as an agent and, thus, also have an aim (List and Pettit 2011, ch.3). Organizations, for example, whose internal life is regulated by a set of organizational rules (to which naturally only the members of the organization are bound and not all members of a society), might also be plausibly conceived as following an aim - this is the aim, which is specified by the internal organizational rules: provision of teaching in a school organization, for example, or provision of research in a research institute or profit seeking in a corporation. But the order of activities that we call "science" is not a deliberate arrangement made by somebody, a taxis, to use the classical Greek word. It is a kosmos, a grown order exhibiting orderly structures which are the product of the action of many individuals, but not the product of a human design (Hayek, 1973/1982, 37). It constitutes an arena of activities which has not been made deliberately - therefore, it cannot legitimately be said to have a particular aim.

The debate about the ways that progress is tied to the aim of science is hence largely misplaced. All three principal approaches to scientific progress relate to three views of the aim of science (Bird, 2016, 546): a) science allegedly aims at solving scientific problems and makes progress when it solves such problems (Kuhn, 1970, Laudan 1977, 1981), b) science allegedly aims at truth and makes progress when it gets closer to the truth (Oddie, 2014, Niiniluoto, 2014) or c) science allegedly aims at knowledge and makes progress when it adds to the stock of knowledge (Bird, 2007). Some other well- 
known views of the aim of science like Popper's view that it consists in finding satisfactory explanations $(1972,191)$ or van Fraassen's view that it consists in empirical adequacy $(1980,12)$ can be accommodated as versions of one of the above. All of them are untenable, because they make progress parasitic on a specific aim of science, as if science were a deliberate collective enterprise. The only plausible question, on the contrary, is whether and how the diverse aims of individual scientists (Elliott and McKaughan, 2014) and scientific organizations produce outcomes in a process of social interaction that are appraised positively with reference to diverse values. All these approaches to scientific progress are important in themselves and it is not my claim that they should all be rejected. They offer alternative views on how scientific progress should be conceptualized adopting alternative epistemological approaches on how the structure of reality can be grasped. In this paper I will avoid endorsing any particular view of scientific progress adopting instead an ecumenical stance which will be hopefully made clearer in section 5. What I do reject, however, is the notion that one should favor or choose one of the approaches solely on the grounds that it allegedly fulfils a specific "aim of science".

\section{Institutions and the Self-Organization of Science}

Karl Popper $(1945,1957)$ was the first to elaborate an institutional theory of scientific progress. He suggested as a starting point for such a theory "to try to imagineconditions under which progress would be arrested. [...] How could we arrest scientific and industrial progress? By closing down, or by controlling scientific periodicals and other means of discussion, by suppressing scientific congresses and conferences, by suppressing Universities and other schools, by suppressing books, the printing press, writing, and, in the end, speaking. All these things which indeed might be suppressed (or controlled) are social institutions. Language is a social institution without which scientific progress is unthinkable, since without it there can be neither science nor a growing and progressive tradition. Writing is a social institution, and so are the organizations for 
printing and publishing and all the other institutional instruments of scientific method. Scientific method itself has social aspects. Science, and more especially scientific progress, are the results not of isolated efforts but of the free competition of thought. For science needs ever more competition between hypotheses and ever more rigorous tests. And the competing hypotheses need personal representation, as it were: they need advocates, they need a jury, and even a public. This personal representation must be institutionally organized if we wish to ensure that it works. And these institutions have to be paid for, and protected by law. Ultimately, progress depends very largely on political factors; on political institutions that safeguard the freedom of thought: on democracy (Popper, 1957, p. 154f.)

Polanyi has presented science as an arena that exemplifies the principle of spontaneous coordination by mutual adjustment. It is a field in which "self-coordination of independent initiatives leads to a joint result which is unpremediated by any of those who bring it about" (Polanyi, 1962, 55). The metaphor of the invisible-hand can be used here, in order to describe the mechanisms that are at work transforming the diverse private interests into a specific order, aggregating the dispersed individual activities into the patterned outcome (Ullmann-Margalit, 1978, 267f.).

Building on the work of these pioneers, I would like to highlight three distinct, but interconnected mechanisms that help coordinating individual and organizational scientific activities and give rise to specific scientific outcomes.

The first is scientific competition which is an evolutionary process of trial and error among individual scientists and organizations pursuing many different aims varying from the search for truth to peer recognition and monetary rewards. Scientific agents engage in problem solving activities which include constant choices under conditions of scarcity. Competition for recognition among peers for scientific achievements like publications or experiments can only take place, if sufficient support for resources is provided for the problem solving scientists. Insofar, the purposes of scientists are connected with the purposes of agents outside the arena of science and this is the way by which science is connected with other social domains like markets, politics, religion etc. Competition for peer recognition is thus tied up with competition for resources (even more so, if one 
takes into consideration that scientific outcomes have to a great degree the quality of a public good in the economic sense, a complex problematic that cannot be tackled here).

The second mechanism is the emergence and adoption of the informal institutions of science that are comprised from what is commonly known as the Ethos of Science (Merton, 1942/1973, 268f), that is the moral rules that scientists adopt, and the conventions and social norms that scientists internalize during their apprenticeship as young researchers. Although moral rules have a universal character, this does not necessarily mean that they are also followed, and in fact many scientists break them. The conventions of the scientific inquiry can be diverse and include codes of communication between scientists, diverse quotation rules etc. The social norms of science most importantly include the methodological rules, that is, rules of collecting data, assessing evidence, constructing models, conducting experiments etc. They comprise the epistemic norms of the scientific community.

Finally, the third mechanism relates to the content and enforcement of the formal institutions of science, that is the sum of legal rules intended to regulate the scientific process that are imposed by the organs of the state (Gascoigne, 2019). These rules are the outcome of the political process and are backed by more or less efficient administrations. They can also vary tremendously, historical examples including the rules enforced by the Papal states to the rules regulating science in the former Soviet Union.

The interconnection of these three mechanisms shapes an institutionally constrained scientific competition. The arena that we have called science is both highly competitive and highly cooperative. The specific mix of competition and cooperation depends on the concrete way that the institutional framework of science affects competition. During their socialization process, the individuals who later become scientists have learnt the conventions, moral rules and social norms of the scientific community they live. When founding research centers and running universities, the agents are already familiar with the legal rules, and they have learnt the degree to which the state protects or infringes their rights. Because they have gone through the same learning history, individuals and organizations largely share the same informal and formal institutions, i.e. the rules of the 
competitive game that make them the specific actors of the specific scientific game they are engaged in. They define the cooperative element of science.

The systematic integration of the institutional framework into the study of science (Jarvie, 2001) leads to a series of insights, the most important being that it offers the basis of determining the content of the scientific competitive process. Institutions determine what actions are permitted in the competition process, i.e. which parameters of scientific activity are allowed and which are not. Scientific agents are driven by the incentives rooted in the institutions to focus on those activities which are allowed. Hence, by allowing scientific agents only limited action parameters, the institutions channel their innovative potential to a specific direction. If the institutional structure allowed extensive genes manipulation of humans, for example, individual scientists and scientific organizations would invent respective sophisticated techniques and suitable skills would be developed over time.

Beyond this, institutions determine the speed of the scientific competitive process. The dynamics of the competitive process depend on the payoffs, i.e. the utility increase expected by the scientific agents engaging in specific scientific activities. The strength of these incentives, however, depends on the institutional framework, which can vary considerably. Patent laws, to take just one obvious example, regulate the rate of scientific inventions in any specific scientific domain, because it ensures that the patent owner will reap all possible monetary benefits from a scientific discovery.

The institutionally constrained competition determines, thus, the blend of cooperation and competition among the participants in the game of science. The metaphor of the invisible hand (Leonard, 2002, 143), is a way to describe the simultaneous working of the three distinct mechanisms referred to above. There is nothing that guarantees that such an invisible-hand process will give rise to emergent unintended outcomes which are in some sense "beneficial" (Hull, 1997). The opposite is very often the case - the emergent patterns might indeed be "pernicious" 3 . The outcomes of the game of science are

\footnotetext{
${ }^{3}$ Even James Buchanan, the liberal economist and Nobel Laureate (1977/2001, 99), having the case of markets in mind, but stating a more general point about invisible hand explanations, has
} 
historically contingent (Kitcher 1993, 2001). Their quality decisively depends on the intricate mix of informal and formal institutions and the way they structure the competitive efforts of the participating scientists and organizations. It is, thus, the specific content of the informal and formal institutions that structure the competitive game in an appropriate way that enable the advancement of science to take place.

\section{The Institutionalization of Competition and Criticism}

The informal and formal institutions of modern science that have come to prevail in a long evolutionary process in the West are due to a historical contingency. The informal institutions encapsulating the critical tradition originating in Ancient Greek philosophy (Popper, 1963, p. 26) weakened in the course of many centuries and revived again during the Scientific Revolution. The emergence of competitive political structures, on the other hand, led to the increase of individual freedom (Bernholz et al. 1998, Jones 2003) and allowed the expression of critical ideas without pernicious consequences for the critic. An intricate mix of informal and formal institutions has come to prevail in most parts of the world in the modern era which increased the freedom of expression which in turn gave rise to a free competition of ideas. The organizational structures of modern universities which have emerged in a gradual secularization process have become decisive in pooling intellectual and material resources offering a secure platform for the generation and critical discussion of abstract theoretical and practical problems.

Science is, thus, embedded in these broader normative structures of the modern world. What appears to distinguish them from other social arenas, religion for example, is the sophistication and systematicity by which empirical evidence is generated and assessed, something that is enabled by the social and cultural arrangements encapsulated in the institutional framework of science (Longino, 1990, 2002). It is the possibility of criticism provided by this framework which acts as a corrective to the error-prone problem-solving

observed that they "may be as applicable to 'orders' that are clearly recognized to be undesirable as to those that are recognized to be desirable". 
activities in which scientists, like ordinary people, are engaged; errors ranging from fallacious mental models that do not give an accurate presentation of the environment to fallacious inferences (including confirmation biases, erroneous probabilistic calculations and much more). To the extent that this auto-correcting process of individual scientists and scientific organizations is enabled by the prevailing institutional framework sustainable scientific progress takes place.

This claim does not hinge upon the concrete conceptualization of scientific progress in terms of problem-solving, of truthlikeness or of growth of knowledge. I would like, thus, to embrace an ecumenism with respect to the diverse notions of scientific progress. In other words, I would not like my argument to be held hostage to the details of some particularly nuanced version of scientific progress. I hold that the idea of scientific progress is comprehensible without necessarily invoking a specific criterion of scientific progress or offering a formal definition of it. The focus of my claim is that the institutions of science permit scientists to circumvent their inherent cognitive limitations and to improve their activities by means of criticism. Scientific progress manifests itself in virtue of the invention and advancement of multiple ways to accurately represent reality and successfully intervene in the natural and social world.

\section{6. "Well-Ordered Science": A Constitutional Interpretation}

I would like now to turn to the normative dimension of the issue that interests us. Is the arena that we call modern science worth protecting? If yes, why, by whom, how exactly and at what level? Although Paul Feyerabend was certainly the first to reflect and provide a concrete proposal on the role of science in a democratic society (which favors the control of the judgments of scientists by elected committees of laymen ${ }^{4}$ ), Philip Kitcher

\footnotetext{
${ }^{4}$ See Feyerabend $(1978,96)$ : "(I)t would not only be foolish but downright irresponsible to accept the judgment of scientists and physicians without further examination. If the matter is important, either to a small group or to society as a whole, then this judgment must be subjected to the most painstaking scrutiny. Duly elected committees of laymen must examine whether the
} 
should be credited for working out a consistent ideal of a well-ordered science (2011, p. 106): "science is well-ordered when its specification of the problems to be pursued would be endorsed by an ideal conversation, embodying all human points of view, under conditions of mutual engagement". The point of departure is that modern science was not planned (Kitcher 2011, p. 98), but rather a historical contingency grown out of the initial impulse of the members of the Royal Society, who were essentially members of a club, that is "gentlemen, free and unconfin'd" as they described themselves. The task is to find the appropriate locus of science as a prominent part of the system of public knowledge with respect to the ways it contributes to and is constrained by the goals of democracy (Kitcher 2011, p. 86). The general issue is, thus, how to embed a spontaneously emerged system of public knowledge within the fundamental rules of a polity organized as a democratic order.

There are two ways to address this issue, which is fundamentally about the governance of science. The first is by means of constructing an ideal and of proposing appropriate ways to realize the ideal. This is the way Kitcher favors: well-ordered science is an ideal, something at which our practices should aim and the key is to identify procedures for attaining or approximating the ideal. Kitcher proposes a series of alternatives that could enable citizens to engage in discussions with scientists in order to jointly determine what would be significant projects to pursue and the resources that should be devoted to them. A real world deliberation is a way to approximate the ideal deliberation required by wellordered science. A fruitful way to interpret this approach is to give it a constitutional interpretation: the ideal can be approached by a series of constitutional arrangements introduced deliberately and by cultivating an accompanying constitutional culture of conversation. This will eventually guarantee that the fundamental values that should guide the scientific endeavors reflect the ideal of a well-ordered science.

Although Kitcher contends that (2011, p. 125) "without some understanding of where you want to go, efforts to improve on the status quo will be leaps in the dark", I would like to propose an alternative approach that stresses comparative evaluation and choice 
rather than approximation of an ideal. Instead of focusing exclusively or at all on the identification of a fully well-ordered science, the comparative approach that I would like to suggest concentrates on ranking alternative constitutional arrangements, asking whether some arrangement makes for a "better" or "worse" science.

\section{The Constitution of Science: A Comparative Approach}

The constitutional level is the highest level at which the institutional framework of science can be anchored. The constitutional rules are the institutions of highest generality regulating a domain of social interaction. If the arena that we call science is worth protecting, then this must primarily occur at the highest level, the constitutional.

Endorsing this view, however, that is endorsing the view that science is worth protecting at the constitutional level, does not answer the question how exactly this should be done nor about the appropriate content of the constitutional rules. What must be stressed in any case is that the acceptance and indeed the availability of an ideal approach is neither sufficient nor necessary. To consider an analogy, the fact that a person regards The Starry Night of van Gogh as the best fresco in the world, does not reveal how she would rank a Gaugin against a Cézanne. The search for an ideal well-ordered science might be an engaging task in itself, but it hardly gives us information about the comparative merits of many constitutional arrangements. In making a judgment that some constitutional rule $x$ is better than an alternative rule $y$, we do not need to invoke the identification that some quite different alternative $z$ is the "best" or "right" constitutional rule. ${ }^{5}$

Besides, different societies have evolved along different trajectories, so that working out an ideal for the appropriate place of science in them may not be feasible, and it must certainly undergo adaptation as these societies continue to evolve and priorities change.

\footnotetext{
5 Amartya Sen [2006, p. 222] makes a similar point in juxtaposing what he calls the "transcendental approach to justice" to the "comparative approach to justice".
} 
A comparative approach is certainly vastly more operational than the provision of a general model able to serve as a reference, which applies to all times and under all conditions. The concrete specification of the constitutional rules that govern scientific activities must proceed from an analysis of the prevailing situation, and it must get by without an atemporal abstract ideal.

To provide an obvious example: throughout most of history, scientific activities have been organized either purely privately or as an ecclesiastical affair. Even in these early periods the appropriate place of science in a polity was still a constitutional issue: even if there is no public spending on scientific activities nor publicly run organizations that hosted such activities, the need of taking a stance towards these activities at the highest level remained intact. When the monopoly of organized violence by the state is used not only to tax citizens in order to finance scientific activities, but also to run state owned agencies where scientific activities are conducted, the need for constitutional arrangements takes a thoroughly different shape. Finally, when the commercialization of science reenters a scene dominated for some time by public or semi-public organizational structures, constitutional arrangements reflecting more nuanced evaluations are necessary. In other words, the search for an adequate constitution of science is a permanent task.

The autonomy of science is a mirage if it is supposed to state a requirement that the agents of science, individuals and organizations, are to lay the constitutional rules in order to regulate their activities by themselves and for themselves. Science will remain ipso facto fundamentally heteronomous, as long as it is conducted in a territory where the fundamental rules are laid by the agents of a state which controls violence - unless the agents and the scientists are identical, something which is largely only a theoretical possibility. Both the methodological rules and the moral rules of science, can help maintain a domain where informal rules will provide decisive normative guidance to the participants to the game of science; but the right to pursue scientific activities can ultimately only be granted by the state. Science can never be entirely self-governed. The constitutional question is to determine the extent and specification of this right and the philosophical task consists in the provision of arguments to answer this question. 
The issue is whether and to what extent the state should grant a specific protected domain to scientific agents - individuals and organizations - guaranteed by constitutional provisions and less general laws. In other words, the issue is about appropriately delineating a protected domain to science vis-á-vis other arenas of social activity like, for example, religion or alternative systems of public knowledge; and in the last consequence it is about the appropriate ways of conflict resolution. The character of such a conflict resolution is more like arbitration than negotiation. To the extent that a philosopher participates in the task of providing arguments for a successful arbitration, she need not herself assume the role of a negotiator: the philosophical arbitrator need not herself be party to the dispute.

In the context of the contemporary democracies of the West, a major challenge that needs be arbitrated has to do with successfully addressing what I would like to call the paradox of liberal democracy ${ }^{6}$. Modern representative democracies are typically constitutional democracies, in which only certain issues are subject to the operation of the majority principle. In other words, at any moment of time people or their representatives can make collective decisions on a vast range of issues by following an appropriate voting procedure after a period of deliberation, but by no means on all issues. In fact, the issues that are regarded as most important are issues that are not subject to majority voting. Reintroducing slavery in the US, for example, is not something that can be voted for in a referendum or as part of the agenda of a political party in elections. A series of such issues are decided upon in critical junctures of the history of a state, and the decisions make up part of a constitution. ${ }^{7}$ Many constitutional provisions in the democracies of the West protect basic individual liberties, typically by securing rights of the citizens from state invasion. The paradox of liberal democracy consists exactly in this tension. On the one hand, the majority principle seems to be desirable because it can sufficiently accommodate the preferences of the citizens and thus express the public sovereignty. On the other hand, the principle of protecting rights of individuals (and groups) restricts the sovereignty of the people: if the people and their representatives decide by majority

\footnotetext{
${ }^{6}$ The first who has clearly seen and articulated this problematic and introduced the term "paradox of liberal democracy" is, according to my knowledge, Aristides Hatzis $(2015,227 \mathrm{ff})$.

${ }^{7}$ On theories of constitutional change, see Voigt [1999].
} 
voting to violate the rights, the constitution and the agents entrusted with its protection will prevent them. This inherent conflict in every constitutional democracy is arbitrated at the highest level by stipulating which issues are to be decided on majoritarian grounds by following specific procedures and which issues should not be subject to any kind of majority voting. The Ninth Amendment of the United States Constitution, introduced due to the attempts of James Madison, characteristically expresses this tension: "The enumeration in the Constitution, of certain rights, shall not be construed to deny or disparage others retained by the people".

The paradox of liberal democracy takes a specific form with respect to science. When considering the appropriate governance of science, a major task beyond determining the content of the respective provisions using the comparative approach, is to determine which issues should be anchored in the constitution and which should be subject to majority voting. The freedom of expression and the freedom of scientific research are obvious cases of liberties to be anchored in the constitution for both epistemological and political reasons. ${ }^{8}$ But other liberties which prima facie do not directly have to do with research are also relevant, for example, the right to private property. (The US Constitution protects private property rights mainly through the Fifth Amendment's Takings or Just Compensation Clause: "nor shall private property be taken for public use without just compensation"). Intellectual property rights and their protection are of obvious importance for scientific research, but other rights also anchored in constitutions are essential for science. Determining whether they should be at all anchored in the constitution is an important task. Naturally, ordinary legislation about science will remain

\footnotetext{
${ }^{8}$ For reasons of space I cannot go deeper into this issue. For a very useful discussion see Wilholt [2010], who traces the variations of the argument in favor of freedom of research to the early modern defenders of the freedom of philosophizing including Campanella, Descartes, Milton and Spinoza. John Stuart Mill's famous argument for intellectual freedom as stated in his On Liberty, ch.2, by appeal to the fallibility of human judgment was preceded by the German philosopher Nicolas Gundling, who had already stated it in a speech delivered at the University of Halle in 1711 and by Christian Wolff's description of the mechanism of mutual criticism in 1728. For a discussion and further references see Wilholt [2010, p. 175].
} 
an issue determined by majority voting, though even in constitutional democracies there is no guarantee that transient majorities will produce worthy outcomes. ${ }^{9}$

Turning very briefly to the case of authoritarian regimes ${ }^{10}$ the governance of science in them will depend on the degree of control that the authoritarian ruler or group wishes to exert on scientific activities. This will in turn depend on the structure of the preferences of the ruler, the time horizon (which will be longer in case the ruling political party is powerful and, thus, able to constrain the ruler) and other factors. The existence of constitutional arrangements regulating science in an authoritarian regime will definitely be an improvement compared to the alternative situation of inexistence of such arrangements. The mere fact that rules are recorded in a written form in the most important legal document of a country offers more security to the scientists undertaking research. The content and enforcement mechanisms of constitutional legislation will be radically different than in the case of a democratic regime, but according to the comparative approach endorsed here, it will represent an improvement vis-à-vis the completely idiosyncratic wishes of an autocratic ruler or ruling party.

\section{Conclusion}

Scientific progress depends on a series of institutional arrangements that have partly evolved spontaneously and partly emerged deliberately by state action. The social arena that we call science is the incubator of multiple and diverse theoretical constructs that

\footnotetext{
${ }^{9}$ There is also an international aspect to this question, but due to lack of space I cannot tackle it here. See, for example Hans Albert [2010, p. 409]: "With regard to its institutions, science can be compared with the international network of financial markets. In the constitution of this system there are no central agencies like the state, which are able to enforce conditions for its functioning that would be valid in all regions. It is, indeed, possible that the legislation of a state undermines its financial stability and in this way causes a crisis, but that this does not exert a strong negative influence on conditions in other areas of the world. Similarly, national regulations may ruin the scientific institutions and traditions of a society that are relevant for the progress of science without affecting the international network of scientific activities."

${ }^{10}$ I would like to thank an anonymous referee for drawing my attention to this issue.
} 
provide the most accurate representations of reality available and the most effective means to intervene successfully in the natural and social world. If scientific progress is valued positively then its institutional foundations must be protected. An appropriate Constitution of Science offers the most effective protection of the scientific enterprise, but the search for its adequate content is a permanent task to be accomplished in a permanent constitutional dialogue. 


\section{References}

Albert, H. [2010]: "The Economic Tradition and the Constitution of Science", Public Choice, 144, pp. 401-411.

Bargh, John A. and Tanya L. Chartrand. 1999. "The Unbearable Automaticity of Being", American Psychologist, vol. 54, pp. 462-479.

Bernholz, Peter, Manfred E. Streit and Roland Vaubel. 1998. Political Competition, Innovation and Growth. Berlin: Springer.

Bicchieri, Cristina. 2006. The Grammar of Society. Cambridge: Cambridge University Press.

Bicchieri, Cristina. 2016. Norms in the Wild. Oxford: Oxford University Press.

Bird, Alexander. 2007. "What Is Scientific Progress?". Nô̂s 41, 64-89.

Bird, Alexander. 2016. "Scientific Progress". In The Oxford Handbook of Philosophy of Science, ed. Paul Humphreys. Oxford: Oxford University Press, 544-563.

Bloor, David. 1976/1991. Knowledge and Social Imagery, 2nd. edition, Chicago: The University of Chicago Press.

Bresson, Alain. 2016. The Making of the Ancient Economy: Institutions, Markets, and Growth in the City States. Princeton: Princeton University Press.

Buchanan, James. 2001. "Law and the Invisible Hand". In his Moral Science and Moral Order, the Collected Works of James M. Buchanan Vol. 17, Indianapolis: The Liberty Press, 96-109.

Coase, Ronald. 1937. "The Nature of the Firm." Economica 4, 386-405.

Coase, Ronald. 1960. "The Problem of Social Cost." Journal of Law and Economics 3, 144. 
Coleman, James. 1990. Foundations of Social Theory. Cambridge/Mass.: Harvard University Press.

DiMaggio, Paul and Walter Powell. (eds.) 1991. The New Institutionalism in Organizational Analysis. Chicago: Chicago University Press.

Dixit, Avinash, Skeath, Susan and Reiley, David. 2015. Games of Strategy. 4th edition, New York: W.W.Norton.

Elliott, Kevin C. and Daniel, J. McKaughan. 2014. "Nonepistemic Values and the Multiple Goals of Science". Philosophy of Science, 81, 1-21.

Elster, Jon. 1989. Nuts and Bolts for the Social Sciences. Cambridge: Cambridge University Press.

Ensminger, Jean. 1992. Making a Market: The Institutional Transformation of an African Society. Cambridge: Cambridge University Press.

Ensminger, Jean and Joseph Henrich (eds.). 2014. Experimenting with Social Norms: Fairness and Punishment in Cross-Cultural Perspective. New York: Russell Sage Publications.

Ferguson, Adam. 1767/1966. An Essay on the History of Civil Society. Edinburgh: Edinburgh University Press.

Feyerabend, P. (1978): Science in a Free Society, London: New Left Books.

Gascoigne, John. 2019. Science and the State. Cambridge: Cambridge University Press.

Gigerenzer, Gerd. 2008. Rationality for Mortals: How People Cope with Uncertainty, Oxford: Oxford University Press.

Gigerenzer, Gerd. 2019. "Axiomatic Rationality and Ecological Rationality", in: Synthese, online first DOI https://doi.org/10.1007/s11229-019-02296-5

Guala, Francesco. 2016. Understanding Institutions. Princeton: Princeton University Press. 
Hall, Peter A. 1986. Governing the Economy: The Politics of State Intervention in Britain and France. Oxford: Polity.

Hall, Peter and Rosemary Taylor. 1998. "Political Science and the Three New Institutionalisms". In Institutions and Social Order, eds. Karol Soltan, Eric Uslaner and Virginia Haufler, Ann Arbor: University of Michigan Press, 15-43.

Hatzis, Aristides. 2015. "Moral Externalities: An Economic Approach to the Legal Enforcement of Morality", in: Law and Economics. Philosophical Issues and Fundamental Questions, (eds.) Hatzis, Aristides and Mercuro, Nicholas, London and New York: Routledge, pp. 226-244.

Hayek, Friedrich A. von. 1960. The Constitution of Liberty. London and New York: Routledge.

Hayek, Friedrich A. von. 1972/1986. Rules and Order, Vol. I of Law, Legislation and Liberty. London and New York: Routledge.

Hayek, Friedrich A.von. 1976/1982. The Mirage of Social Justice, Vol. II of Law, Legislation and Liberty, London and New York: Routledge.

Heiner, Ronald. 1993. "The Origin of Predictable Behavior". American Economic Review, 73, 560-595.

Hobbes, Thomas. 1651/1991. Leviathan. Cambridge: Cambridge University Press.

Hull, David. 1988. Science as a Process. Chicago: The University of Chicago Press.

Hull, David. 1997. "What's Wrong with Invisible-Hand Explanations?" Philosophy of Science, 64, S117-S126.

Jarvie, Ian. 2001. The Republic of Science: The Emergence of Popper's Social View of Science 1935-1945. Atlanta: Rodopi.

Jones, Eric L. 2003. The European Miracle. 3rd. Edition. Cambridge: Cambridge University Press. 
Kitcher, Philip. 1993. The Advancement of Science. Oxford: Oxford University Press.

Kitcher, Philip. 2001. Science, Truth and Democracy. Oxford: Oxford University Press.

Kitcher, P. (2011): Science in a Democratic Society, New York: Prometheus Books.

Knight, Jack. 1992. Institutions and Social Conflict. Cambridge: Cambridge University Press.

Kuhn, Thomas. 1970. The Structure of Scientific Revolutions, 2nd. edition. Chicago: The University of Chicago Press.

Latour, Bruno and Steve Woolgar. 1979.1986. Laboratory Life: The Social Construction of Scientific Facts, 2nd. edition, Princeton: Princeton University Press.

Laudan, Larry. 1977. Progress and Its Problems. Toward a General Theory of Scientific Growth. Berkeley: University of California Press.

Laudan, Larry. 1981. "A Problem-Solving Approach to Scientific Progress". In Ian Hacking (ed.): Scientific Revolutions, Oxford: Oxford University Press, 144-155.

Leonard, T. C. 2002. "Reflections on Rules in Science: An Invisible-Hand Perspective". Journal of Economic Methodology, 9, 141-168.

Levi, Margaret. 1988. Of Rule and Revenue. Berkeley, Los Angeles, London: University of California Press.

List, Christian and Pettit, Philip. 2011. Group Agency. Oxford: Oxford University Press.

Longino, Helen. 1990. Science as Social Knowledge. Princeton: Princeton University Press.

Longino, Helen. 2002. The Fate of Knowledge. Princeton: Princeton University Press.

Mahoney, James and Kathleen Thelen (eds.). 2015. Advances in Comparative-Historical Analysis, Cambridge: Cambridge University Press. 
Mantzavinos, C. 2001. Individuals, Institutions and Markets. Cambridge: Cambridge University Press.

Mantzavinos, C., North, Douglass and Shariq, Syed. 2004. "Learning, Institutions, and Economic Peformance". Perspectives on Politics, 2, 75-84.

Mantzavinos, C. 2013. "Explanatory Games". Journal of Philosophy, CX, 602-632.

Mantzavinos, C. 2016. Explanatory Pluralism. Cambridge: Cambridge University Press.

Merton, Robert. 1942/1973. "The Normative Structure of Science". In Merton, Robert. The Sociology of Science. Chicago: The University of Chicago Press, 268-278.

Meyer, John. 2010. "World Society, Institutional Theories, and the Actor". Annual Review of Sociology, 36, 1-20.

Moe, Terry. 2005. "Power and Political Institutions". Perspectives on Politics, 3, 215233.

Mueller, Dennis. 2003. Public Choice III. Cambridge: Cambridge University Press.

Nee, Victor and Mary Brinton (eds.). 1998. The New Institutionalism in Sociology, New York: Russell Sage.

Niiniluoto, Ilka. 2014. Scientific Progress as Increasing Verisimilitude. Studies in History and Philosophy of Science Part A, 46, 73-77.

North, Douglass C. 1981. Structure and Change in Economic History, New York: W. W. Norton.

North, Douglass C. 1990. Institutions, Institutional Change and Economic Performance, Cambridge: Cambridge University Press.

North, Douglass C. 1994. "Economic Performance Through Time." American Economic Review 84, 359-368.

North, Douglass C. 2005. Understanding the Process of Economic Change. Princeton: Princeton University Press. 
North, Douglass C., John Wallis and Barry Weingast. 2009. Violence and Social Orders, Cambridge: Cambridge University Press.

Ober, Josiah. 2015. The Rise and Fall of Classical Greece, Princeton: Princeton University Press.

Oddie, Graham. 2014. "Truthlikeness". In E.N.Zalta (ed.). The Stanford Encyclopedia of Philosophy. Summer 2014 ed.

Ostrom, Elinor. 1990. Governing the Commons: The Evolution of Institutions for Collective Action, Cambridge: Cambridge University Press.

Ostrom, Elinor. 2005. Understanding Institutional Diversity, Princeton: Princeton Univesity Press.

Pierson, Paul. 2004. Politics in Time: History, Institutions and Social Analysis, Princeton: Princeton University Press.

Polanyi, Michael. 1962. "The Republic of Science". Minerva 1, 54-73.

Popper, Karl (1945): The Open Society and its Enemies, London and New York: Routledge.

Popper, Karl (1957): The Poverty of Historicism, London and New York: Routledge.

Popper, Karl (1963): Conjectures and Refutations. The Growth of Scientific Knowledge, London and New York: Routledge.

Popper, Karl. 1972. "The Aim of Science" In his Objective Knowledge. Oxford: Oxford University Press, 191-205.

Riker, William. 1980. "Implications from the Disequlibrium of Majority Rule for the Study of Institutions", American Political Science Review 74, 432-447.

Rorty, Richard. 1979. Philosophy and the Mirror of Nature, Princeton: Princeton University Press. 
Sen, A. [2006]: "What Do We Want from a Theory of Justice?", Journal of Philosophy, vol. CIII, 175-208.

Shepsle, Kenneth. 1986. "Institutional Equlibrium and Equilibrium Institutions", in Political Science: The Science of Politics, ed. Weisberg, Herbert, New York: Agathon, 51-81.

Shepsle, Kenneth. 1989. "Studying Institutions: Some Lessons from the Rational Choice Approach", Journal of Theoretical Politics 1, 131-147.

Shepsle, Kenneth. 2006. "Rational Choice Institutionalism" in Oxford Handbook of Political Institutions, eds. Rhodes R.A.W., Sarah Binder and Bert Rockman, Oxford: Oxford University Press, 23-38.

Simon, Herbert. 1983. Reason in Human Affaris, Stanford: Stanford University Press.

Thelen, Kathleen. 2004. How Institutions Evolve. The Political Economy of Skills in Germany, Britain, the United States and Japan, Cambridge: Cambridge University Press.

Tsebelis, George. 2002. Veto Players. How Political Institutions Work, Princeton: Princeton University Press.

Tsebelis, George. 2017. "The Time Inconsistency of Long Constitutions", Summer Bulletin of American Academy of Arts and Sciences, 42-45.

Ullmann-Margalit, Edna. 1978. "Invisible-hand Explanations", Synthese, 39, 263-291.

Van Fraassen, Bas. 1980. The Scientific Image. Oxford: Oxford University Press.

Voigt, S. [1999]: Explaining Constitutional Change, Aldershot: Edward Elgar, 1999.

Whitehead, Alfred. 1911. An Introduction to Mathematics, London: Williams and Norgate.

Wilholt, T. [2010]: "Scientific Freedom: Its Grounds and Their Limitations", Studies in History and Philosophy of Science, 41, pp. 174-181. 
Williamson, Oliver. 1985. The Economic Institutions of Capitalism, New York: Free Press.

Williamson, Oliver. 1996. The Mechanisms of Governance. Oxford: Oxford University Press. 